\title{
Human papillomavirus infection \& anal cytological abnormalities in HIV-positive men in eastern India
}

\author{
Abhilasha Gautam ${ }^{1 \dagger}$, Jaya Chakravarty ${ }^{1 *+} \mathbb{D}$, Vijay Kumar Singh ${ }^{1}$, Amrita Ghosh², Shashi Bhushan Chauhan ${ }^{1}$, \\ Madhukar Rai ${ }^{1}$ and Shyam Sundar ${ }^{1}$
}

\begin{abstract}
Background: Oncogenic Human papillomavirus (HPV) infections are closely associated with anal cancer which is high among human immunodeficiency virus (HIV) infected males. There are no data regarding anal HPV infection and cytological abnormalities in HIV positive males receiving free therapy in the national program. Thus, this crosssectional study was performed to assess the prevalence and risk factors of anal HPV infection and cytological abnormalities in HIV positive males.

Methods: We screened $126 \mathrm{HIV}$-positive male patients attending the antiretroviral treatment center (ART) between 2014 and 2015 with anal papanicolaou smear cytology and HPV-DNA testing. HPV-DNA was detected by using polymerase chain reaction (PCR) method with two consensus primer sets E6 and MY09/11 and further analyzed for the presence of various HPV genotype by Sanger sequencing. Risk factors associated with anal cytological abnormalities and HPV infection was analyzed by using univariate and multivariate logistic regression models.

Results: Out of 126, 52 were on antiretroviral therapy. 91\% were married to female partners but during the study 48 (38\%) gave positive history of anal intercourse with other men. Anal cytology was done in 95 patients, out of which 60 (63.15\%) had cytological abnormalities. LSIL (low-grade squamous intraepithelial lesions) was present in 27 (45\%), ASCUS (atypical squamous cells of undetermined significance) in 31 (52\%) and ASC-H (atypical squamous cells cannot exclude a high-grade squamous intraepithelial lesion) in 2 (3.33\%). In multivariate analysis, the risk factors for cytological abnormality were presence of history of anal intercourse $(\mathrm{OR}, 6.1 ; 95 \% \mathrm{Cl}, 2.0-18.7)$ and $\mathrm{WHO}$ stage III \& IV (OR, 2.7; 95\% Cl, 1.1-7.5). HPV-DNA was detected in 33/119 (27.73\%) patients. The most prevalent HPV type in the study was HPV-16 (10.08\%), other HPV types detected were 18,31,35,17,66,72,52,68 and 107 (17.65\%).
\end{abstract}

Conclusions: High prevalence of anal cytological abnormalities in our study suggests that regular anal Pap smear screening should be done in HIV positive males in the ART center.

Keywords: HPV, HIV, Anal cytology, PCR, Anal cancer, India

\section{Background}

With the scale-up of antiretroviral therapy and longer life expectancy of HIV infected individuals, there is a growing concern about infection-related cancers. Anal cancer is one of the frequent non-AIDS-defining malignancies in the HIV-infected population [1]. In a large study involving

\footnotetext{
* Correspondence: tapadar@gmail.com

${ }^{+}$Abhilasha Gautam and Jaya Chakravarty contributed equally to this work.

1 Department of Medicine, Institute of Medical Sciences, Banaras Hindu

University, Varanasi 221005, India

Full list of author information is available at the end of the article
}

13 cohorts from North America, the unadjusted anal cancer incidence rates per 100,000 person-years were 131 for HIV infected MSM (men having sex with men), 46 for other HIV-infected men, and 2 for HIV-uninfected men [2]. High-grade squamous intraepithelial lesions (HSIL) are considered premalignant and may progress to anal cancer. Risk factors for the development of anal squamous intraepithelial lesion system (SIL) are anal HPV infection, high-risk sexual behavior and HIV infection, especially with lower CD4 levels [3, 4]. HPV infection is known to be a causative factor for both anal SIL and anal cancer [5-7]. 
The age-standardized rates (ASR) of anal cancer in different regions of India varies from 0.1-0.7 per 100,000 men per year [8]. A study from an HIV cancer clinic in India showed that the proportional incidence ratio in HIV-positive males for anal cancer was 10.3 [9]. Despite the known high risk of anal cancer in HIV positive males, there are very few studies in India regarding the prevalence of HPV and anal cytological abnormalities in this population. A small study among HIV positive and negative MSM in India showed that $27.7 \%$ had abnormal anal cytology which was increased in HIV-positive men as compared to HIV-negative men (35\% versus $20 \%, p=0.180$ ) [10]. In another large study of HIV positive MSM in India, the prevalence of oncogenic anal HPV was 49\% [11]. Most of the studies of anal cytological abnormalities and HPV infection have focused on MSM, however, other HIV positive men are also at an increased risk of anal cancer. As of September 2014, 1.88 million PLHIV (people living with HIV/ AIDS) have been registered in 453 National AIDS control organization (NACO) run ART centers in India, $60 \%$ of whom are male patients [12]. Despite the large number of males in the program, there are no studies on anal cytological abnormalities and HPV infection in these patients. Thus, this study was done to assess the prevalence and risk factors of anal HPV infection and anal cytological abnormalities in HIV positive males attending the ART center.

\section{Methods}

\section{Study site}

This cross-sectional exploratory study was conducted between 2014 and 2015 in HIV positive men attending the ART Center. The ART center of Banaras Hindu University (BHU) is one of the largest center in the Eastern part of the country and has approximately 15,000 PLHIV registered in it.

\section{Study population and sample collection}

The study was approved by the Ethics committee of Institute of Medical Sciences, Banaras Hindu University (EC registration No- ECR/526/Inst./UP/2014 Dt-31.1.14). All HIV positive men above the age of 18 , attending the ART centers were eligible for the study. A written informed consent was obtained from all the participants. A detailed history including sexual history was obtained. Baseline demographic data was collected from the cards of the patient maintained in the ART center. CD4+ lymphocyte counts were determined using BD FACS Calibur (FACS Calibur Becton Dickinson Biosciences) and the values were expressed as cells/ $\mu \mathrm{L}$.

Anal samples were taken from the anal squamous-columnar junction of the anal canal. These samples were than separated into two parts, initially a smear was prepared for anal cytology screening and immersed immediately in 95\% alcohol and the other anal scrape sample was collected in $15 \mathrm{ml}$ falcon tube containing $2 \mathrm{ml}$ $1 \mathrm{X}$ phosphate buffered saline (PBS) which was stored at $-20{ }^{\circ} \mathrm{C}$ for DNA extraction and PCR amplification. Cytology smears were evaluated by a pathologist under light microscope and cytological changes were classified according to Bethesda system normal i.e. no cell changes; NILM (negative for intraepithelial lesions and malignancy) which includes inflammatory changes, organisms, atrophic changes and reactive changes; ASCUS (atypical squamous cells of undetermined significance) ; ASCH (atypical squamous cells cannot exclude a highgrade squamous intraepithelial lesion); LSIL (low-grade squamous intraepithelial lesions) and HSIL (high-grade squamous intraepithelial lesions) [13].

\section{DNA extraction and HPV-DNA detection}

HPV-DNA were extracted from epithelial cell suspension by using QIAamp DNA Blood Mini Kit (QIAGEN, Hilden, Germany) according to manufacturer's protocol, isolated DNA were dissolved in $80 \mathrm{ul}$ milli-Q water. Quality and quantity of DNA were checked in NanoDrop Spectrophotometers (Thermo Scientific, USA). After validating the DNA extraction results, samples were stored at $-20^{\circ} \mathrm{C}$ until further processing. To detect HPV, Polymerase chain reaction (PCR) reaction (amplification) was performed by using two different consensus primer sets, E6 consensus primer targeting a 250-bp oncogenic region of the HPV E6 ORF (Open reading frame) [14] and MY09/11 consensus primer targeting a 450-bp region of the HPV L1 ORF in HPV genome [15].

PCR products were viewed by Agarose Gel Electrophoresis (AGE) during optimization procedures, and as needed. $1.4 \%$ agarose gels were prepared for electrophoresis.

\section{Genotyping by sequencing}

All HPV positive PCR products were subjected to sequencing for confirmation of HPV types. DNA sequencing was performed on 3730XL DNA genetic analyzer (Applied Biosystem, USA) using the Big Dye Terminator Cycle Sequencing Ready Reaction Kit version 3.1 (Applied Biosystem, CA, USA) with the E6 and MY09/ 11 consensus primers by SciGenom, Labs Pvt. Ltd., Cochin, Kerala, India. The resulting sequences were compared with HPV sequences of known types using the basic local alignment search tool (BLAST) from the National Centers for Biotechnology Information (NCBI) website (https://blast.ncbi.nlm.nih.gov). HPV types $16,18,31,33,35,39,45,51,52,56,58,59,68,73$ and 82 were considered as highly oncogenic highrisk (HR), while HPV types 26, 53 and 66 as probably oncogenic. HPV types $6,11,40,42,43,44,54,61,70$, 
72 and 81 were considered as low oncogenic potential lowrisk (LR) [16].

\section{Statistical analysis}

Statistical analysis was performed using the Statistical Package for Social Sciences (SPSS) software, version 16. For Bi-variable logistic regression analysis, variables were compared between HPV positive-negative and Pap smear cytology between abnormal-normal in HIVpositive men by performing chi-square test, t-test or the Mann-Whitney U-test where appropriate. Binary logistic regression analysis was performed to analyze the associations between variables. Results were estimated by means of odds ratio (OR) and $95 \%$ confidence intervals $(\mathrm{CI})$. Two-tailed $P$ values less than 0.05 were considered statistically significant.

\section{Result}

\section{Baseline characteristics of cases}

We screened 126 HIV-positive men in this study. Baseline characteristics of the HIV positive men are given in Table 1 . The mean age was $35.37 \pm 8.2$ years, median $\mathrm{CD} 4+$ cell counts at baseline was $129 / \mu \mathrm{L}$ and at the time of sample collection was $253 / \mu \mathrm{L}$. Mean weight and mean hemoglobin was $49.53 \pm 8.45 \mathrm{Kg}$ and $11.2 \pm$ $1.73 \mathrm{~g} / \mathrm{dl}$ respectively. 74 patients were treatment naive and 52 were on ART with a mean duration of treatment of 12 (9-22) months. The documented risk for HIV was heterosexual contact for 125 males in the records of the center and $91 \%$ were married to female partners. However, during the study $48(38 \%)$ gave positive history of anal intercourse with other men.

\section{Prevalence and analysis of anal cytology}

Out of 126 cases, 31 slides were broken, lost or found to be inadequate for result. Finally, 95 slides were examined out of which 60 (63.15\%) had cytological abnormalities, of which 27 (45\%) cases had LSIL, 31 (52\%) had ASCUS and $2(3.33 \%)$ had ASC-H. None of the patients had HSIL. 33 (34.73\%) slides were negative for any cytological abnormalities and $2(2.10 \%)$ had reactive inflammatory changes. In the univariate analysis risk factors for anal cytological abnormalities were history of anal intercourse (OR, 6.4; 95\% CI, 2.1-18.7), with $p$-value of 0.00 , history of active tuberculosis (OR, 2.4; 95\% CI, 1.1-6.1), with p-value of 0.04 , low CD4 count $<350 / \mu \mathrm{l}$ (OR, 2.9; 95\% CI, 1.1-7.7) with p-value of 0.02 , WHO clinical stage III + IV (OR, 2.8; 95\% CI, 1.1-7.1) with $\mathrm{p}$-value of 0.02 . In multivariate logistic regression analysis, history of anal intercourse (OR, 6.1; 95\% CI, 2.018.7) $\mathrm{p}$-value 0.00 and WHO clinical stage (III + IV) (OR, 2.7; 95\% CI, 1.1-7.5), p-value 0.04 were risk factor for anal cytological abnormalities given in (Table 1).

\section{HPV genotype distribution}

Out of 126 cases enrolled in the study, 7 samples had inadequate DNA, therefore a total of 119 samples were examined out of which 33/119 (27.73\%) were positive for HPV-DNA. Among men with history of anal intercourse the prevalence of HPV was 15/48 (31.25\%) much higher than in heterosexual men where it was $18 / 78$ (23\%). In the univariate and multivariate logistic regression analysis no significant risk factor was identified for anal HPV detection by PCR (Table 1). All HPV- positive samples were subjected to direct sequencing method for confirmation of HPV types. It revealed 10 different high-risk (HR) HPV genotypes and all 33 HPV-positive sequences were recognized. HPV-16 the most prevalent HPV type in the study was, identified in $(10.08 \%, 12$ / 119) followed by HPV-31 (4.2\%, 5/119), HPV-35 (3.36\%, 4/119) HPV-18 (2.5\%, 3/119), HPV-17, HPV-52, HPV-72 (1.6\% each, 2/119) and HPV-66, HPV-68, HPV-107 (0.84\% each, $1 / 119)$.

\section{Correlation between HPV-PCR and anal cytology}

The overall prevalence of HRHPV was 27.73\% among the HIV positive men.

Among those with NILM, ASCUS, and LSIL, 24.24, 28.57 and $44.44 \%$ respectively were HPV positive (Table 2 ).

\section{Discussion}

This is the first study among HIV positive men attending the ART center of the National program. An interesting finding in this exploratory cross-sectional study was that $38 \%$ of our study participants gave a history of anal intercourse with other men while in all except one participant the documented risk for HIV was heterosexual in the records of the center. In India due to fear of stigma, discrimination and criminalization of homosexuality many men fail to disclose their true sexual orientation. $91 \%$ of these men were either currently or previously married i.e. were or had been in heterosexual relationship. Studies have also shown that $23-42 \%$ of MSM are married to women in India thereby easily mistaken for being heterosexual [17-19].These findings in our study suggest that although bisexuality among HIV positive men in our set up is common, elicitation and documentation of this fact is poor.

However, the recent decriminalization of homosexuality in India will go a long way in improving disclosures regarding their sexual orientation.

Prevalence of HPV in HIV positive males in our study was $27.73 \%$. This is similar to a study of HIV positive heterosexual males by Gandra et al., which showed the overall prevalence of HR-HPV and abnormal cytology to be $28 \%$ [20]. While it was much lower than that observed in HIV-infected MSM in a meta-analysis of 53 studies, where the pooled prevalence of anal HPV 
Table 1 Baseline characteristics and risk factor analysis

\begin{tabular}{|c|c|c|c|c|c|c|c|c|c|c|c|}
\hline \multirow[t]{3}{*}{ Baseline characteristics } & & \multicolumn{6}{|c|}{$\begin{array}{l}\text { Risk factor analysis for abnormal and normal anal cytology in } \\
\text { HIV positive men }(n=95)\end{array}$} & \multicolumn{4}{|c|}{$\begin{array}{l}\text { Risk factor analysis for HPV positive and } \\
\text { negative in HIV positive men }(n=119)\end{array}$} \\
\hline & & \multirow{2}{*}{$\begin{array}{l}\text { Frequency } \\
\text { No. (\%) } \\
\text { Positive } \\
(n=60)\end{array}$} & \multirow{2}{*}{$\begin{array}{l}\text { Frequency } \\
\text { No. (\%) } \\
\text { Negative } \\
(n=35)\end{array}$} & \multicolumn{2}{|l|}{ Uni-variate } & \multicolumn{2}{|c|}{ Multi-variate } & \multirow{2}{*}{$\begin{array}{l}\text { Frequency } \\
\text { No. (\%) } \\
\text { Positive } \\
(n=33)\end{array}$} & \multirow{2}{*}{$\begin{array}{l}\text { Frequency } \\
\text { No. }(\%) \\
\text { Negative } \\
(n=86)\end{array}$} & \multicolumn{2}{|c|}{ Uni-variate } \\
\hline & & & & \multicolumn{2}{|l|}{$(95 \% \mathrm{Cl})$} & $\begin{array}{l}\text { OR } \\
(95 \% \mathrm{Cl})\end{array}$ & $P$-value & & & $\begin{array}{l}\mathrm{OR} \\
(95 \% \mathrm{Cl})\end{array}$ & $P$-value \\
\hline \multirow[t]{2}{*}{ Age (years) } & $<35$ year & $27(45.0)$ & $18(51.4)$ & $\begin{array}{l}0.7 \\
(0.3-1.6)\end{array}$ & 0.54 & & & $15(45.5)$ & $41(47.7)$ & $\begin{array}{l}0.9 \\
(0.4-2.0)\end{array}$ & 0.82 \\
\hline & & $33(55.0)$ & $17(48.6)$ & 1 & & & & $18(54.5)$ & $45(52.3)$ & 1 & \\
\hline \multirow[t]{2}{*}{ Education } & Illiterate & $12(20.0)$ & $5(14.3)$ & $\begin{array}{l}1.5 \\
(0.4-4.6)\end{array}$ & 0.48 & & & $1(3.0)$ & $16(18.6)$ & $\begin{array}{l}0.1 \\
(0.0-1.0)\end{array}$ & 0.05 \\
\hline & & $48(80.0)$ & $30(85.7)$ & 1 & & & & $32(97.0)$ & $70(81.4)$ & 1 & \\
\hline \multirow[t]{2}{*}{ Employment } & Unemployed & $30(50.0)$ & $14(40.0)$ & $\begin{array}{l}1.5 \\
(0.6-3.4)\end{array}$ & 0.34 & & & $13(39.4)$ & $36(41.9)$ & $\begin{array}{l}0.9 \\
(0.3-2.0)\end{array}$ & 0.80 \\
\hline & & $30(50.0)$ & $21(60.0)$ & 1 & & & & $20(60.6)$ & $50(58.1)$ & 1 & \\
\hline \multirow[t]{2}{*}{ Urban/rural } & Rural & $45(75.0)$ & $26(74.3)$ & $\begin{array}{l}0.9 \\
(0.3-2.5)\end{array}$ & 0.93 & & & $26(78.8)$ & $61(71.0)$ & $\begin{array}{l}0.6 \\
(0.2-1.7)\end{array}$ & 0.38 \\
\hline & & $15(25.0)$ & $9(25.7)$ & 1 & & & & $7(21.2)$ & $25(29.0)$ & 1 & \\
\hline \multirow[t]{2}{*}{ Marital status } & $\begin{array}{l}\text { Married, Widowed, } \\
\text { Divorced }\end{array}$ & $6(10.0)$ & $1(2.9)$ & $\begin{array}{l}0.2 \\
(0.0-2.2)\end{array}$ & 0.22 & & & $6(18.2)$ & $4(4.7)$ & $\begin{array}{l}0.2 \\
(0.0-0.8)\end{array}$ & 0.22 \\
\hline & Never married & $54(90.0)$ & $34(97.1)$ & 1 & & & & $27(81.8)$ & $82(95.3)$ & 1 & \\
\hline \multirow[t]{2}{*}{ History of active tuberculosis } & Present & $24(40.0)$ & $8(22.9)$ & $\begin{array}{l}2.4 \\
(1.1-6.1)\end{array}$ & 0.04 & & & $9(27.3)$ & $35(40.7)$ & $\begin{array}{l}0.5 \\
(0.2-1.3)\end{array}$ & 0.17 \\
\hline & & $36(60.0)$ & $27(77.1)$ & 1 & & & & $24(72.7)$ & $51(59.3)$ & 1 & \\
\hline \multirow[t]{2}{*}{ History of Alcohol intake } & Yes & $46(76.7)$ & $27(77.1)$ & $\begin{array}{l}0.9 \\
(0.3-2.6)\end{array}$ & 0.95 & & & $24(72.7)$ & $70(81.4)$ & $\begin{array}{l}0.6 \\
(0.2-1.5)\end{array}$ & 0.30 \\
\hline & & $14(23.3)$ & $8(22.9)$ & 1 & & & & $9(27.3)$ & 16 (18.6) & 1 & \\
\hline \multirow[t]{2}{*}{ History of Smoking } & Yes & $48(80.0)$ & $28(80.0)$ & $\begin{array}{l}1.0 \\
(0.3-2.8)\end{array}$ & 0.99 & & & $26(78.8)$ & $72(83.7)$ & $\begin{array}{l}0.7 \\
(0.2-1.9)\end{array}$ & 0.52 \\
\hline & & $12(20.0)$ & $7(20.0)$ & 1 & & & & $7(21.2)$ & $14(16.3)$ & 1 & \\
\hline \multirow[t]{2}{*}{$\begin{array}{l}\text { History of Anal intercourse } \\
\text { with other male. }\end{array}$} & Present & $31(51.7)$ & $5(14.3)$ & $\begin{array}{l}6.4 \\
(2.1-18.7)\end{array}$ & $0.00^{*}$ & $\begin{array}{l}6.1 \\
(2.0-18.7)\end{array}$ & $0.00^{*}$ & $15(45.5)$ & $29(33.7)$ & $\begin{array}{l}1.6 \\
(0.7-3.7)\end{array}$ & 0.23 \\
\hline & & $29(48.3)$ & $30(85.7)$ & 1 & & & & & & & \\
\hline \multirow[t]{2}{*}{ No. of Sexual partners } & >one & $50(83.3)$ & $27(77.1)$ & $\begin{array}{l}1.5 \\
(0.5-4.4)\end{array}$ & 0.39 & & & $26(78.8)$ & $70(81.4)$ & $\begin{array}{l}0.8 \\
(0.3-2.2)\end{array}$ & 0.74 \\
\hline & & $10(16.7)$ & $8(22.9)$ & 1 & & & & $7(21.2)$ & $16(18.6)$ & 1 & \\
\hline \multirow[t]{2}{*}{ History of hemorrhoid } & Present & $27(45.0)$ & $11(31.4)$ & $\begin{array}{l}1.7 \\
(0.7-4.2)\end{array}$ & 0.19 & & & $15(45.5)$ & $35(40.7)$ & $\begin{array}{l}1.2 \\
(0.5-2.7)\end{array}$ & 0.63 \\
\hline & & $33(55.0)$ & $24(68.6)$ & 1 & & & & $18(54.5)$ & $51(59.3)$ & & \\
\hline \multirow[t]{2}{*}{$\begin{array}{l}\text { Anal symptoms (bleeding, } \\
\text { discharge, pain, irritation) }\end{array}$} & Present & $26(43.3)$ & $11(31.4)$ & $\begin{array}{l}1.6 \\
(0.6-4.0)\end{array}$ & 0.25 & & & $15(45.5)$ & $35(40.7)$ & $\begin{array}{l}1.2 \\
(0.5-2.8)\end{array}$ & 0.55 \\
\hline & & $34(56.7)$ & $24(68.6)$ & 1 & & & & $18(54.5)$ & $51(59.3)$ & 1 & \\
\hline WHO HIV clinical staging & $I I I+I V$ & $30(50.0)$ & $9(25.7)$ & $\begin{array}{l}2.8 \\
(1.1-7.1)\end{array}$ & $0.02^{*}$ & $\begin{array}{l}2.7 \\
(1.1-7.5)\end{array}$ & $0.04^{*}$ & $14(42.4)$ & $37(43.0)$ & $\begin{array}{l}0.9 \\
(0.4-2.1)\end{array}$ & 0.95 \\
\hline & $I+\|$ & $30(50.0)$ & $26(74.3)$ & 1 & & & & $19(57.6)$ & $49(57.0)$ & 1 & \\
\hline & $<350$ & $50(83.3)$ & $22(62.9)$ & $\begin{array}{l}2.9 \\
(1.1-7.7)\end{array}$ & $0.02^{*}$ & $\begin{array}{l}1.6 \\
(0.5-4.7)\end{array}$ & 0.37 & $26(78.8)$ & $61(71.0)$ & $\begin{array}{l}1.5 \\
(0.5-3.9)\end{array}$ & 0.38 \\
\hline (at the time of study) & & $10(16.7)$ & $13(37.1)$ & 1 & & & & $7(21.2)$ & $25(29.0)$ & 1 & \\
\hline Weight (kg) & $<40$ & $7(11.7)$ & $6(17.1)$ & $\begin{array}{l}0.6 \\
(0.1-2.0)\end{array}$ & 0.45 & & & $4(12.1)$ & $10(11.6)$ & $\begin{array}{l}1.0 \\
(0.3-3.6)\end{array}$ & 0.94 \\
\hline & & $53(88.3)$ & $29(82.9)$ & 1 & & & & $29(87.9)$ & $76(88.4)$ & 1 & \\
\hline Hemoglobin (g/dl) & $<10 \mathrm{mg} / \mathrm{dl}$ & $14(23.3)$ & $7(20.0)$ & $\begin{array}{l}1.5 \\
(0.5-4.3)\end{array}$ & 0.70 & & & $7(21.2)$ & $19(22.0)$ & $\begin{array}{l}0.9 \\
(0.3-2.5)\end{array}$ & 0.91 \\
\hline
\end{tabular}


Table 1 Baseline characteristics and risk factor analysis (Continued)

\begin{tabular}{|c|c|c|c|c|c|c|c|c|c|c|}
\hline \multirow[t]{5}{*}{ Baseline characteristics } & & \multicolumn{5}{|c|}{$\begin{array}{l}\text { Risk factor analysis for abnormal and normal anal cytology in } \\
\text { HIV positive men }(n=95)\end{array}$} & \multicolumn{4}{|c|}{$\begin{array}{l}\text { Risk factor analysis for HPV positive and } \\
\text { negative in HIV positive men }(n=119)\end{array}$} \\
\hline & & \multirow{4}{*}{$\begin{array}{l}\text { Frequency } \\
\text { No. (\%) } \\
\text { Positive } \\
(n=60)\end{array}$} & \multirow{4}{*}{$\begin{array}{l}\text { Frequency } \\
\text { No. (\%) } \\
\text { Negative } \\
(n=35)\end{array}$} & \multirow{2}{*}{\multicolumn{2}{|c|}{ Uni-variate }} & \multirow[t]{2}{*}{ Multi-variate } & \multirow{4}{*}{$\begin{array}{l}\text { Frequency } \\
\text { No. (\%) } \\
\text { Positive } \\
(n=33)\end{array}$} & \multirow{4}{*}{$\begin{array}{l}\text { Frequency } \\
\text { No. (\%) } \\
\text { Negative } \\
(n=86)\end{array}$} & \multicolumn{2}{|c|}{ Uni-variate } \\
\hline & & & & & & & & & & \\
\hline & & & & $\overline{O R}$ & $P$-value & $P$-value & & & \multirow{2}{*}{$\begin{array}{l}\text { OR } \\
(95 \% \mathrm{Cl})\end{array}$} & \multirow[t]{2}{*}{$P$-value } \\
\hline & & & & \multicolumn{2}{|l|}{$(95 \% \mathrm{Cl})$} & $(95 \%$ Cl) & & & & \\
\hline & & $46(76.7)$ & $28(80.0)$ & 1 & & & $26(78.8)$ & $67(78.0)$ & 1 & \\
\hline \multirow[t]{2}{*}{$\begin{array}{l}\text { Presence of anal wart } \\
\text { on visual inspection }\end{array}$} & Present & $14(23.3)$ & $7(20.0)$ & $\begin{array}{l}1.5 \\
(0.5-4.3)\end{array}$ & 0.70 & & $7(21.2)$ & $21(24.4)$ & $\begin{array}{l}0.8 \\
(0.3-2.1)\end{array}$ & 0.71 \\
\hline & & $46(76.7)$ & $28(80.0)$ & 1 & & & $26(78.8)$ & $65(75.6)$ & 1 & \\
\hline \multirow[t]{2}{*}{ ART status } & Pre ART & $32(53.3)$ & $19(54.3)$ & $\begin{array}{l}0.9 \\
(0.4-2.2)\end{array}$ & 0.92 & & $23(69.7)$ & $48(55.8)$ & $\begin{array}{l}1.8 \\
(0.7-4.2)\end{array}$ & 0.17 \\
\hline & On ART & $28(46.7)$ & $16(45.7)$ & 1 & & & $10(30.3)$ & $38(44.2)$ & 1 & \\
\hline
\end{tabular}

infection was 93 and $74 \%$ for any type and any high-risk type, respectively [21]. Studies have shown that the HPV detection rate is critically affected by the choice of PCR primer sets [22]. This could be one of the reasons for the low prevalence of HPV in our population despite the fact that $38 \%$ of the participants were bisexual. Use of multiple primer sets would definitely increase the detection rate of HPV-DNA as observed in our unpublished data. As HPV types 16 and 18 causes nearly $90 \%$ of anal cancers, vaccination against HPV could be an effective strategy of preventing this malignancy. HPV vaccination is recommended for all immunocompromised patients up to 26 years of age and up to 40 years in MSM by European AIDS clinical society [EACS] and similar guidelines would also be relevant in India.

Abnormal anal cytology was present in 63.15\% (60/ 95 ) in our study, $33 \%$ of them were also HPV positive. This is much higher than the $20-28 \%$ of cytological abnormality observed in recent studies in heterosexual HIV positive men [20, 23]. While it is similar (66-67\%) to studies in HIV positive MSM [24]. Participants with poor WHO clinical stage and history of anal intercourse were also at risk for anal SIL similar to other studies [25]. Although none of the patients had HSIL, 27 had LSIL and 12 (44\%) out of them were HPV positive. In a study that included 346 HIV-infected and 262 HIV-uninfected MSM, $62 \%$ of HIV-infected and 36\% of
HIV-uninfected men with LSIL at baseline progressed to HSIL [26]. This suggests that PLHIV with baseline cytological abnormality should be followed up to observe whether the lesions are progressing or not.

At present New York State screening (NYS) guidelines for anal cancer recommend that all HIV positive patients undergo annual visual and digital rectal exam plus an anal Pap screening for anal cancer. While the EACS recommends anal cancer screening for MSM and those with HPV associated dysplasia. In India, there are no recommendations for screening of HIV positive males as there is no data regarding the prevalence of anal cytological abnormality and HPV prevalence in HIV positive males. Anal cancer screening is a simple tool which could increase early detection of anal cancer in HIV positive males.

The limitations of our study were its cross-sectional nature, only one pathologist examined the slides, 31 slides count not be evaluated for cytology and the inability to detect multiple HPV types. Further, the results of our study cannot be generalized as these samples were only from HIV positive males in eastern India and studies from other part of the country needs to be done.

\section{Conclusions}

This is the first study on anal cytological abnormalities and HPV infection among HIV positive males attending

Table 2 Correlation between results of HPV-PCR and Anal cytology

\begin{tabular}{|c|c|c|c|c|c|}
\hline \multirow{2}{*}{$\begin{array}{l}\mathrm{HPV}^{-P C R^{a}} \\
(n=119)\end{array}$} & \multicolumn{5}{|l|}{ Anal Cytology } \\
\hline & Normal cytology $(n=33)$ & $\operatorname{ASCUS}(n=28)$ & ASC-H $(n=2)$ & $\mathrm{LSIL}(n=27)$ & Inadequate Smear $(n=29)$ \\
\hline $\begin{array}{l}\text { HPV Positive } \\
33(27.73 \%)\end{array}$ & $8(24.24 \%)$ & $8(28.57 \%)$ & 0 & $12(44.44 \%)$ & $5(17.24 \%)$ \\
\hline $\begin{array}{l}\text { HPV Negative } \\
86(72.26 \%)\end{array}$ & $25(75.75 \%)$ & $20(71.43 \%)$ & $2(100 \%)$ & $15(55.56 \%)$ & $24(82.76 \%)$ \\
\hline
\end{tabular}

NOTE: ${ }^{\text {a }}$ HPV-PCR was done in 119 samples as 7 patients with inadequate DNA. Among these 7 patients, 2 had normal cytology, 3 had ASCUS and 2 had inadequate smear

${ }^{\mathrm{b}}$ Anal Cytology was performed in 95 samples 
the National program in India. The prevalence of HPV infection in our study was $27.73 \%$, which was much lower than HIV positive MSM but similar to that in HIV-negative MSM. At present there is no recommendation for HPV testing for HIV positive MSM or heterosexual males. However, HPV vaccination for PLHIV could be an effective strategy to decrease HPV related malignancy. $38 \%$ of subjects documented to be heterosexual in the ART center had a history of anal intercourse in our study thus efforts should be taken to elicit this history .

There was high prevalence of anal cytological abnormalities $(63.15 \%)$ in our study subjects which was higher than studies of HIV positive heterosexual males and similar to HIV positive MSM. The main risk factor identified for abnormal anal cytology was history of anal intercourse and poor WHO clinical stage III\&IV. Many guidelines recommend screening of PLHIV for anal cancer. In India there are no recommendations for screening of HIV positive males as there is no data regarding the prevalence of anal cytological abnormality in this cohort. Anal cancer screening as done for cervical cancer in women is a simple tool which could potentially reduce both incidence and mortality by allowing for early detection of anal cancer precursor lesions especially in HIV positive bisexual males.

\section{Abbreviations}

ART: Antiretroviral therapy; ASC-H: Atypical squamous cells cannot exclude a highgrade squamous intraepithelial; ASCUS: Atypical squamous cells of undetermined significance; BHU: Banaras Hindu University; BLAST: Basic Local Alignment Search Tool; Cl: Confidence intervals; COE: Center of Excellence; DNA: Deoxyribo nucleic acid; EACS: European AIDS clinical society; HIV: Human immunodeficiency; HPV: Human papillomavirus; HR: High-risk; LR: Low-risk; LSIL: Low-grade squamous intraepithelial lesions; MSM: Men having sex with men; NACO: National AIDS control organization; NCBI: National Centers for Biotechnology Information; NILM: Negative for intraepithelial lesions and malignancy; NYS: New York State screening; OR: Odds ratio; PBS: Phosphate buffered saline; PCR: Polymerase chain reaction; PLHIV: People living with HIV/AIDS; SIL: Squamous intraepithelial lesion system; SPSS: Statistical Package for Social Sciences; UPSACS : Uttar Pradesh State AIDS control society

\section{Acknowledgements}

We would like to extend our thanks to UPSACS (Uttar Pradesh State AIDS control society) for their cooperation. Authors also offer sincere thanks to all the patients and staffs of ART center who participated in this research work. We also thank Neeraj Dwivedi and Sandeep Patel for their help in data analysis.

\section{Funding}

This work was supported by the Center of Excellence (COE), NACO (M18017/ 72/2007/NACO (GF Rd. 6), India. Author AG1 is the recipient of UGC-Rajiv Gandhi National Fellowship (RGNF) financial support as Junior Research Fellow (JRF), India (Award no-201314-RGNF-2013-14-SC-UTT-36942).

\section{Availability of data and materials}

The datasets used and/or analyzed during the current study are available from the corresponding author on reasonable request.

\section{Authors' contributions}

1. JC, SS \& MR: Conceived and designed the study, enrolled subject, performed interpretation and analysis of data, drafted the manuscript 2. AG1, AG 2, VKS \& SBC: collected samples, performed laboratory experiment, performed interpretation and analysis of data, drafted the manuscript 3. AG1, VKS \& JC: Analysis and data interpretation/critically revised the manuscript 4. SS, MR, JC, AG1 \& AG2: reagents/materials/analysis tools 5. AG1, VKS, AG 2, SBC, MR, SS \& JC: Manuscript drafting. All authors read and approved the final manuscript.

\section{Ethics approval and consent to participate}

The study was approved by the Ethics committee of Institute of Medical Sciences, Banaras Hindu University (EC registration No- ECR/526/Inst./UP/ 2014 Dt-31.1.14). All HIV positive men above the age of 18, attending the ART center were eligible for the study. A written informed consent was obtained from all the participants. Baseline demographic data was collected from the cards of the patient maintained in the ART center.

\section{Consent for publication}

Not applicable.

\section{Competing interests}

The authors' declare that they have no competing interests.

\section{Publisher's Note}

Springer Nature remains neutral with regard to jurisdictional claims in published maps and institutional affiliations.

\section{Author details}

'Department of Medicine, Institute of Medical Sciences, Banaras Hindu University, Varanasi 221005, India. ²Department of Pathology, Institute of Medical Sciences, Banaras Hindu University, Varanasi 221005, India.

Received: 29 April 2018 Accepted: 13 December 2018

Published online: 27 December 2018

\section{References}

1. Chia-ching JW, Silverberg MJ, Abrams DI. Non-AIDS-defining malignancies in the HIV-infected population. Curr Infect Dis Rep. 2014;16:406.

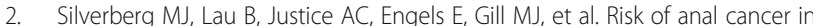
HIV-infected and HIV-uninfected individuals in North America. Clin Infect Dis. 2012;54:1026-34.

3. Palefsky JM, Holly EA, Ralston ML, Arthur SP, Jay N, et al. Anal squamous intraepithelial lesions in HIV-positive and HIV-negative homosexual and bisexual men: prevalence and risk factors. J Acquir Immune Defic Syndr Hum Retrovirol. 1998;17:320-6.

4. Palefsky JM, Shiboski S, Moss A. Risk factors for anal human papillomavirus infection and anal cytologic abnormalities in HIV-positive and HIV-negative homosexual men. J Acquir Immune Defic Syndr. 1994;7:599-606.

5. Chin-Hong PV, Vittinghoff E, Cranston RD, Browne L, Buchbinder S, et al. Age-related prevalence of anal cancer precursors in homosexual men: the EXPLORE study. J Natl Cancer Inst. 2005;97:896-905.

6. Kiviat NB, Critchlow CW, Holmes KK, Kuypers J, Sayer J, et al. Association of anal dysplasia and human papillomavirus with immunosuppression and HIV infection among homosexual men. Aids. 1993:7:43-50.

7. De Vuyst H, Clifford GM, Nascimento MC, Madeleine MM, Franceschi S. Prevalence and type distribution of human papillomavirus in carcinoma and intraepithelial neoplasia of the vulva, vagina and anus: a meta-analysis. Int J Cancer. 2009;124:1626-36.

8. Curado M. P., Edwards, B., Shin H.R., Storm H., Ferlay J., Heanue M. and Boyle P., eds (2007). Cancer Incidence in Five Continents, Vol. IX. IARC Scientific Publications No. 160, Lyon, IARC.

9. Dhir AA, Sawant S, Dikshit RP, Parikh P, Srivastava S, et al. Spectrum of HIV/ AIDS related cancers in India. Cancer Causes Control. 2008;19:147-53.

10. Arora R, Pandhi D, Mishra K, Bhattacharya SN, Yhome VA. Anal cytology and p16 immunostaining for screening anal intraepithelial neoplasia in HIVpositive and HIV-negative men who have sex with men: a cross-sectional study. Int J STD AIDS. 2014;25:726-33.

11. Hernandez AL, Karthik R, Sivasubramanian M, Raghavendran A, Gnanamony $M$, et al. Prevalence of anal HPV infection among HIV-positive men who have sex with men in India. J Acquir Immune Defic Syndr. 2016;71:437.

12. Department of AIDS Control, National AIDS Control Organization, Ministry of Health and Family Welfare, Government of India; 2014. Annual Report 14.

13. Solomon D, Davey D, Kurman R, Moriarty A, O'Connor D, et al. The 2001 Bethesda system: terminology for reporting results of cervical cytology. Jama. 2002;287:2114-9. 
14. Hwang T. Detection and typing of human papillomavirus DNA by PCR using consensus primers in various cervical lesions of Korean women. J Korean Med Sci. 1999;14:593-9.

15. Taherian H, Tafvizi F, Fard ZT, Abdirad A. Lack of association between human papillomavirus infection and colorectal cancer. Prz Gastroenterol. 2014;9:280.

16. Muñoz N, Bosch FX, de Sanjosé S, Herrero R, Castellsagué X, et al. Epidemiologic classification of human papillomavirus types associated with cervical cancer. N Engl J Med. 2003;2003:518-27.

17. Dandona L, Dandona R, Gutierrez JP, Kumar GA, McPherson S, et al. Sex behaviour of men who have sex with men and risk of HIV in Andhra Pradesh. India Aids. 2005;19:611-9.

18. Thomas B, Mimiaga MJ, Kumar S, Swaminathan S, Safren SA, et al. HIV in Indian MSM: reasons for a concentrated epidemic \& strategies for prevention. Indian J Med Res. 2011;134:920.

19. Kumar B, Ross MW. Sexual behaviour and HIV infection risks in Indian homosexual men: a cross-cultural comparison. Int J STD AIDS. 1991;2:442-4.

20. Gandra S, Azar A, Wessolossky M. Anal high-risk human papillomavirus infection and high-grade anal intraepithelial neoplasia detected in women and heterosexual men infected with human immunodeficiency virus. HIV/ AIDS (Auckland, NZ) 7: 29; 2015.

21. Machalek DA, Poynten M, Jin F, Fairley CK, Farnsworth A, et al. Anal human papillomavirus infection and associated neoplastic lesions in men who have sex with men: a systematic review and meta-analysis. The lancet oncology. 2012;13:487-500

22. Kado S, Kawamata Y, Shino Y, Kasai T, Kubota K, et al. Detection of human papillomaviruses in cervical neoplasias using multiple sets of generic polymerase chain reaction primers. Gynecol Oncol. 2001;81:47-52.

23. Darwich L, Videla S, Cañadas M-P, Piñol M, García-Cuyàs F, et al. Distribution of human papillomavirus genotypes in anal cytological and histological specimens from HIV-infected men who have sex with men and men who have sex with women. Dis Colon rectum. 2013;56:1043-52.

24. Ciobotaru B, Leiman G, John TS, Hyman N, Ramundo M, et al. Prevalence and risk factors for anal cytologic abnormalities and human papillomavirus infection in a rural population of HIV-infected males. Dis Colon rectum. 2007;50:1011-6.

25. Weis SE, Vecino I, Pogoda JM, Susa JS, Nevoit J, et al. Prevalence of anal intraepithelial neoplasia defined by anal cytology screening and highresolution anoscopy in a primary care population of HIV-infected men and Women. Dis Colon Rectum. 2011;54(4):433-4.

26. Palefsky JM, Holly EA, Ralston ML, Jay N, Berry JM, et al. High incidence of anal high-grade squamous intra-epithelial lesions among HIV-positive and HIV-negative homosexual and bisexual men. Aids. 1998;12:495-503.

Ready to submit your research? Choose BMC and benefit from:

- fast, convenient online submission

- thorough peer review by experienced researchers in your field

- rapid publication on acceptance

- support for research data, including large and complex data types

- gold Open Access which fosters wider collaboration and increased citations

- maximum visibility for your research: over $100 \mathrm{M}$ website views per year

At $\mathrm{BMC}$, research is always in progress.

Learn more biomedcentral.com/submissions 